\title{
Performance of Litopenaeus vannamei at different levels of daily protein intake and carbohydrate/protein ratios in low fishmeal content feeds
}

\author{
Rendimiento de Litopenaeus vannamei a diferentes niveles de ingesta diaria de proteína y proporciones \\ carbohidrato/proteína en alimentos formulados con baja inclusión de harina de pescado \\ Ruvalcaba Márquez Juan Carlos', Eliza Martínez Antonio', Píndaro Álvarez Ruíz², Ramón Casillas Hernández ${ }^{3}$, \\ Humberto Mejía Ruíz', *Francisco Javier Magallón Barajas' \\ Centro de Investigaciones Biológicas del Noroeste, S.C. \\ 2 Centro Interdisciplinario de Investigación para el Desarrollo Integral Regional, Instituto Politécnico Nacional. \\ ${ }^{3}$ Instituto Tecnológico de Sonora.
}

\section{ABSTRACT}

The increase in shrimp aquaculture production relates to the development of increasingly efficient formulated feeds and feed management strategies. Protein, considered the most important ingredient in feeds, represent the highest economic and environmental cost. Therefore, determining the appropriate amount of protein is essential to maintain a balance between performance, cost, and environment in aquaculture systems. The objective of this study was to determine the mathematical functions of Daily Protein Intake (DPI), to evaluate feeds with different Carbohydrate/ Crude protein $(\mathrm{CBH}: \mathrm{CP})$ ratio and low inclusion of fishmeal for $L$. vannamei juveniles culture. The adjusted mathematical function that best represented aquaculture feeding practices was $\mathrm{DPI}=44.7(\mathrm{BW})^{-0.714}$. In the first experiment, four variants of DPI $(80,100,120$ and $140 \%)$ at a constant $\mathrm{CBH}: \mathrm{CP}$ ratio was carried out, finding the best performance at $120 \%$. In the second experiment, diets with five levels of $\mathrm{CBH}: \mathrm{CP}$ (g $\mathrm{CBH}$ : g crude protein; 2.1, 1.5, 1.1, 0.8 and 0.6) with constant Lip:CP were evaluated using the same DPI function. The $\mathrm{CBH}: \mathrm{CP}$ levels variation had a significant effect on growth parameters, feed conversion rate, nitrogen retention and protein, determining that feed with $2.1 \mathrm{CBH}: \mathrm{CP}$ ratio presents the best results when using $\mathrm{DPI}=53.64(\mathrm{BW})^{-0.714}$.

Keywords: Daily protein intake, nitrogen retention, L. vannamei performance, carbohydrates:protein rates.

\section{RESUMEN}

El aumento de la producción acuícola de camarón se ha logrado gracias al desarrollo de alimentos balanceados y estrategias de alimentación más eficientes. La proteína es considerada el insumo más importante para el desarrollo de los organismos, y representa el mayor costo económico y ambiental. El objetivo de este estudio fue determinar las funciones matemáticas de ingesta diaria de proteína (IDP), con objeto de utilizarlas para evaluar dietas con diferentes proporciones de carbohidratos/proteína cruda (CHO:CP) y baja inclusión de harina de pescado en juveniles de $L$. vannamei. El modelo matemático que representó de mejor manera las prácticas de alimentación acuícolas evaluadas fue IDP $=44.7(P C)^{-0.714}$. En el primer experimento se utilizaron cuatro niveles de variación de IDP (80, 100, 120 y $140 \%$ a una proporción $\mathrm{CHO}: \mathrm{CP}$ constante, encontrando el mejor rendimiento con IDP $120 \%$. En el segundo experimento; se evaluaron dietas con cinco niveles de $\mathrm{CHO}: \mathrm{CP}$ (g CHO:g proteína cruda; $2.1,1.5,1.1,0.8$ y 0.6) usando la mejor función de IDP. La variación de los niveles de CHO:CP tuvieron un efecto significativo en crecimiento, el factor de conversión alimenticia, retención de nitrógeno y eficiencia proteica, determinando que la dieta con $\mathrm{CHO}: \mathrm{CP}$ de 2.1 presentó mejores resultados con IDP $=53.64(P C)^{-0.714}$.

Palabras clave: Ingesta diaria de proteína, retención de nitrógeno, desempeño de L. vannamei, proporción carbohidrato: proteína.

\section{INTRODUCTION}

Shrimp aquaculture production has shown an accelerated increase in the last two decades, reaching 4.966 million tons in 2018 for L. vannamei, corresponding to $54 \%$ of crustacean aquaculture (FAO, 2020). These production levels have been possible thanks to the culture intensification, where the use of formulated feeds and feed management has been a fundamental strategy (Wasielesky et al., 2006). Shrimp feed quality include protein, fatty acids, carbohydrates, vitamins, minerals, and additives (Wang et al., 2015). Protein is one of the most important nutrients required for growth (Hu et al., 2008) and accounts the major economic and environmental cost in diets formulation, favoring the increase of nitrogen residuals to the environment (Tacon and Akiyama, 1997; Lee and Lee, 2018; Gil-Nuñez et al., 2020). The proper use of protein favors rapid growth (Guroy et al., 2012) and water quality in aquaculture systems (Limsuwan and Junratchakoo, 2004). A minimum dietary protein level is required to supply amino acids for normal maintenance of metabolism (Lee and Lee, 2018). Several studies have evaluated the adequate protein requirements in terms of protein levels in feeds, finding the best yields feeding with $36 \%$ (Yaemssoksawat et al., 2008) and $40 \%$ (Liu et al., 2005). Kureshy and Davis (2002) determined the daily protein intake $\left({\mathrm{g} \mathrm{DP} \mathrm{kg}^{-1} \mathrm{BW} \mathrm{d}}^{-1}\right.$ ) for maintenance and maximum growth for $L$. vannamei juveniles at different body weights $(\mathrm{g})$ and protein retentions. In addition

*Autor para correspondencia: Francisco Javier Magallón Correo electrónico: fmagallon04@gmail.com

Recibido: 12 de enero de 2021

Aceptado: 31 de mayo de 2021 
to protein, the development of aquaculture systems requires a precise evaluation for the rest of the energy substrates.

The protein in the diet can be reduced if the energy required comes from another source such as carbohydrates or lipids, which can reduce the emission of residual nutrients and feed costs (Zainuddin et al., 2014). Shrimp require lipids in their diet to perform a series of metabolic functions, where the recommended lipid levels in the diet range between 6 and $10 \%$, with negative effects on growth with values greater than $10 \%$ (González-Félix et al., 2002; Xu et al., 2017; Jannalhulla et al., 2019). Zhang et al. (2013) determined that the effect of lipids could vary depending on the protein, reporting highest growth rates at high inclusion percentages in diets with $34 \%$ protein. Despite the low digestibility of carbohydrates by the shrimp (Shiau, 1997), carbohydrates are often used in formulated feeds as an energy source through the protein-sparing mechanism (Wang et al., 2015), where feeding with frequency of four times per day, diets carbohydrate-rich presents a good performance (Zainuddin et al., 2014).

The importance of protein amount provided is clear in aquaculture, also related to other different nutrients in the feeding of shrimp. On the other hand, there is a lack of studies related to the growth of $L$. vannamei with fixed amounts of protein anchored to different ratios of other nutrients. Thus, the aim of this study was to determine the daily protein intake (DPI) mathematical functions related to body weight, in order to use in experiments to evaluate carbohidrate:crude protein ratios in feeds with low inclusion of fishmeal that present the best performance in terms of growth, protein efficiency and nitrogen retention. The use of mathematical functions for the supply of protein will favor the use of the appropriate amount of this, reducing economic and environmental costs while maintaining good performance, allowing evaluate feed formulas and variation of other energetic substrates such as carbohydrates.

\section{MATERIAL AND METHODS Shrimp feeding tables}

Different shrimp feeding tables reported for L. vannamei aquaculture in several countries or recommended by relevant feed companies were reviewed. Feeding tables used in this study were based on biomass percentages (\%Biomass) for different shrimp Body Weights (g).

\section{DPI mathematical model}

Daily protein intake (g protein $/ \mathrm{kg}$ biomass/day) mathematical function related to $L$. vannamei Body Weight (BW) in grams, was adjusted in this study from experimental data reported by Kureshy and Davis (2002), using selected DPI data for different BWs where Protein Retention (\%) was similar ( $37.2 \%$ in average).

Data from different feeding tables reviewed in this study were transformed to Daily Protein Intake DPI (g protein $/ \mathrm{Kg}$ Biomass/day) related to individual BW and were analyzed to determine the best fit for mathematical functions between both variables, using the same mathematical model mentioned previously. The best fit for DPI mathematical function for all the data reported for $L$. vannamei in an explicit or implicit manner (through feeding tables) was $\mathrm{DPI}=\mathrm{a}(\mathrm{BW})^{\mathrm{b}}$, where DPI is expressed in $\mathrm{g}$ protein/ $\mathrm{Kg}$ biomass/day and BW in grams.

The mathematical function adjusted from data reported by Kureshy and Davis (1992) was considered as $100 \%$ $\mathrm{DPI}$, and four functions were developed as a variation in $20 \%$ between them (80, 100, 120 and $140 \%)$ to cover the explicit or implicit DPI data reviewed for L. vannamei aquaculture at different body weights. These mathematical functions were evaluated experimentally at different levels of DPI and same BW respect to growth, protein efficiency and nitrogen retention using feeds with fixed carbohydrate: crude protein $(\mathrm{CBH}: \mathrm{CP})$ and lipid:crude protein (Lip:CP) ratio.

\section{First trial: DPI mathematical functions related to 80,100 , 120, $140 \%$ DPI levels}

The experiment was carried out in the experimental nutrition laboratory at the Centro de Investigaciones Biológicas del Noroeste S.C. (La Paz, Baja California Sur, México). L. vannamei juveniles $(1 \pm 0.5 \mathrm{~g})$ from Aquacultura Mahr local company, kept under laboratory conditions for one week, were randomly distributed in three experimental units $(60$ $L$ fish tanks) ( $n=12)$ for each DPI level. Shrimp were reared under controlled conditions of salinity $37 \pm 0.5$ psu (practical salinity units), dissolved oxygen ( $\left.6 \pm 1.0 \mathrm{mg} \mathrm{O}_{2} \mathrm{~L}^{-1}\right)$, temperature $\left(28 \pm 1{ }^{\circ} \mathrm{C}\right)$ and photoperiod (12:12h light:dark).

Shrimp were fed with a commercial diet (40\% protein and fixed $\mathrm{CBH}: \mathrm{CP}$ ratio) in four daily rations $(9: 00,12: 00,15: 00$ and 18:00 h) to decrease the amount of feed not eaten according to four DPI levels (80, 100, 120 and $140 \%$ ) for 35 days. The DPI levels were adjusted weekly according to the shrimp body weight and biomass. The shrimp tanks were siphoned every day to remove uneaten food, with a weekly water exchange ( $80 \%)$, to remove organic carbon, nitrogen and phosphorous residuals accumulated during the week. Also, the experimentally selected DPI mathematical function was used to evaluate five experimental low fishmeal feeds with different $\mathrm{CBH}: \mathrm{CP}$ ratios using the same Lipid:Crude protein level and DPI mathematical function.

\section{Formulated diets}

For the second experiment, five diets were formulated with Nutrion ${ }^{\oplus}$ software, using a low inclusion of fish meal (6.5 $\%$; table 1), yeast and soybean meal as protein, sardine oil for lipids and wheat flour as carbohydrate source, to obtain five $\mathrm{CBH}: \mathrm{CP}(2.1,1.5,1.1,0.8$ and 0.6$)$ ratios with the same Lip:CP ratio (table 1). The ingredients were ground in an ultrafine sprayer set at $250 \mu \mathrm{m}$ and mixed with water and a fermented mix of marine yeasts and lactobacilli selection. Once extruded and dried, the diets were subjected to two steps of organic acid and fish oil baths. Table 2 shows the proximal composition of the diets. 
Table 1. Diets composition formulated with five different carbohydrate:protein (crude protein) (CBH:CP) ratios with same lipid:protein (Lip:CP) ratio for L. vannamei. Ingredients are expressed in dry weight (\%).

Tabla 1. Composición de dietas formuladas con cinco proporciones diferentes carbohidrato:proteína (proteína cruda) (CHO:CP) con la misma proporción lipido:proteína (Lip:CP) para L. vannamei. Los ingredientes se expresan en base seca.

\begin{tabular}{|c|c|c|c|c|c|}
\hline Diet & 1 & 2 & 3 & 4 & 5 \\
\hline $\mathrm{CBH}: \mathrm{CP}$ & 2.1 & 1.5 & 1.1 & 0.8 & 0.6 \\
\hline Lip:CP & 0.2 & 0.2 & 0.2 & 0.2 & 0.2 \\
\hline Wheat meal & 51.4 & 37.4 & 23.6 & 16.6 & 8.4 \\
\hline $\mathrm{SPC}^{1}$ & 0 & 0 & 10 & 32.4 & 49.1 \\
\hline Soybean meal & 21.9 & 36 & 36.8 & 20.4 & 11.5 \\
\hline Fishmeal & 6.5 & 6.5 & 6.5 & 6.5 & 6.5 \\
\hline Fish oil & 0.7 & 1 & 1.5 & 1.8 & 2.2 \\
\hline Yeast $^{2}$ & 4 & 4 & 4.5 & 4.5 & 4.5 \\
\hline PM vit ${ }^{3}$ & 2.6 & 2.6 & 2.6 & 2.6 & 2.6 \\
\hline $\mathrm{PM} \mathrm{min}^{4}$ & 6.3 & 6.1 & 5.8 & 5.9 & 5.7 \\
\hline Soybean lecithin & 2.4 & 3.1 & 3.8 & 4.4 & 5 \\
\hline Aminoacids mix ${ }^{5}$ & 0.4 & 0.14 & 0.3 & 0.3 & 0.5 \\
\hline Alginic acid & 2 & 2 & 2 & 2 & 2 \\
\hline Probiotic Mix & 1 & 1 & 1 & 1 & 1 \\
\hline \multirow[t]{2}{*}{ Cellulose } & 0.8 & 0.16 & 1.6 & 1.6 & 1 \\
\hline & 100 & 100 & 100 & 100 & 100 \\
\hline
\end{tabular}

1.- Soybean protein concentrate, 2.- Saccharomyces cerevisiae, 3.- Choline, DL-alpha-tocopherol, retinol, butilated hydroxytoluene, astaxanthin, ascorbic acid, biotin, inositol, folic acid, cholecalciferol, menadione, thiamine, riboflavin, niacin, pantothenic acid, pyridoxine, cobalamin, carnitine. 4.$\mathrm{NaH}_{2} \mathrm{PO}_{4^{\prime}} \mathrm{CaCO}_{3^{\prime}}, \mathrm{KH}_{2} \mathrm{PO}_{4^{\prime}}, \mathrm{MgSO}_{4}-7 \mathrm{H}_{2} \mathrm{O}, \mathrm{ZnSO}_{4}-7 \mathrm{H}_{2} \mathrm{O}, \mathrm{CuSO}_{4}-7 \mathrm{H}_{2} \mathrm{O}, \mathrm{CoCl}_{2^{\prime}}$ $\mathrm{Na} 2 \mathrm{SeO}_{3^{\prime}} \mathrm{Kl}$. 5.- Methionine, arginine, tryptophane. 6.- Formic, propionic, acetic and citric acid.

\section{Second trial: Different levels of $\mathrm{CBH}: \mathrm{CP}$ ratio using same DPI model}

L. vannamei juveniles $(2.5 \pm 0.5 \mathrm{~g})$ were randomly distributed in 15 experimental tanks with $60 \mathrm{~L}$ (12 organisms per aquarium) by triplicate. The feeding was based on the DPI mathematical function selected in the first trial. The shrimp tanks were daily siphoned to remove uneaten feed, with a weakly water exchange ( $40 \%$ ) and environmental conditions like the experiment mentioned above.

\section{Statistical analysis}

The following zootechnical parameters were obtained in both experiments: Weight gain (\%) (WG) $=(($ final weight (g) - initial weight (g) )*100)/ initial weight (g); Specific growth rate $(\%)(S G R)=100 *$ (In final weight $(g)-$ In initial weight $(\mathrm{g})) /$ days of experiment; Survival rate $(\%)=(($ shrimp initial number - dead shrimp number)/shrimp initial number) $x$ 100; Feed conversion ratio $(F C R)=$ feed intake (dry matter) (g)/weight gain (g); Protein efficiency ratio (PER) = wet weight gain (g) / dry protein intake (g).

Homoscedasticity of variances and normality of data were verified by Bartlett and Shapiro Wilk's test. The effect of DPI in the first experiment and dietary CBH:CP in the second one on zootechnical parameters was analyzed separately using one way ANOVA. Differences were considered significant at $p<0.05$ and were indicated to the end of the tables. Differences between means for each group (individual means) were determined using a post hoc Tukey's HSD test.

\section{RESULTS \\ Feeding tables review}

In all the shrimp feeding tables reviewed the daily ration based on biomass (\%) diminish as the Body Weight increase. A greater variability in DPI was found in the feeding ratio based on Biomass percentage for shrimps with BW lower than 5 grams in all analyzed cases; from BW 5 to 12 grams most cases show similar DPI levels. Feeding tables reported for México by Quintero and Roy (2010) and for Honduras by Teichert-Coddington and Rodriguez (1995) show greater feeding ratios from 2 to 18 grams compared to other feeding tables (figure 1).

Table 2. Proximate chemical analysis for formulated diets with five different carbohydrate:protein (crude protein) $(\mathrm{CBH}: \mathrm{CP}$ ) and same lipid:protein (Lip:CP) ratio for L. vannamei.

Tabla 2. Análisis químico proximal de dietas formuladas con cinco proporciones diferentes de

carbohidrato:proteína (proteína cruda) (CHO:CP) con la misma proporción lipido:proteína (Lip:CP) para L. vannamei.

\begin{tabular}{cccccccccc}
\hline Diet & $\begin{array}{c}\text { CBH:CP } \\
(\mathbf{g} / \mathbf{g})\end{array}$ & $\begin{array}{c}\text { Lip:CP } \\
(\mathbf{g} / \mathbf{g})\end{array}$ & $\begin{array}{c}\text { Moisture } \\
(\%)\end{array}$ & $\begin{array}{c}\text { Crude protein } \\
(\%)\end{array}$ & $\begin{array}{c}\text { Crude lipids } \\
\text { (\%) }\end{array}$ & $\begin{array}{c}\text { Crude } \\
\text { fiber }(\%)\end{array}$ & $\begin{array}{c}\text { Ash } \\
(\%)\end{array}$ & $\begin{array}{c}\text { NFE } \\
\text { (\%) }\end{array}$ & $\begin{array}{c}\text { Energy } \\
\text { (cal/g) }\end{array}$ \\
\hline 0 & 1.07 & 0.2 & $6.4 \pm 0.1$ & $40.4 \pm 0.2$ & $8.1 \pm 0.1$ & $1.0 \pm 0.1$ & $7.2 \pm 0.04$ & 43.3 & $4809.6 \pm 3.1$ \\
\hline 1 & 2.1 & 0.2 & $8.8 \pm 0.10$ & $26.5 \pm 0.24$ & $5.1 \pm 0.03$ & $0.4 \pm 0.10$ & $10.0 \pm 0.01$ & 57.9 & $4091 \pm 0.61$ \\
\hline 2 & 1.5 & 0.2 & $11.5 \pm 0.1$ & $32.7 \pm 0.1$ & $6.3 \pm 0.1$ & $0.6 \pm 0.00$ & $10.8 \pm 0.1$ & 49.6 & $4276.8 \pm 3.9$ \\
\hline 3 & 1.1 & 0.2 & $9.1 \pm 0.1$ & $37.9 \pm 0.1$ & $7.5 \pm 0.1$ & $1.0 \pm 0.1$ & $10.6 \pm 0.1$ & 42.9 & $4398.1 \pm 6.1$ \\
\hline 4 & 0.8 & 0.2 & $11.2 \pm 0.1$ & $42.2 \pm 0.1$ & $8.5 \pm 0.03$ & $1.8 \pm 0.0$ & $10.34 \pm 0.1$ & 37.1 & $4488.0 \pm 4.8$ \\
\hline 5 & 0.6 & 0.2 & $9.7 \pm 0.1$ & $46.1 \pm 0.1$ & $9.1 \pm 0.1$ & $0.7 \pm 0.1$ & $10.2 \pm 0.01$ & 33.8 & $4608.1 \pm 1.2$ \\
\hline
\end{tabular}

Diet 0: Commercial Feed for First trial, diets 1-5: Experimental formulated feeds for second trial. 


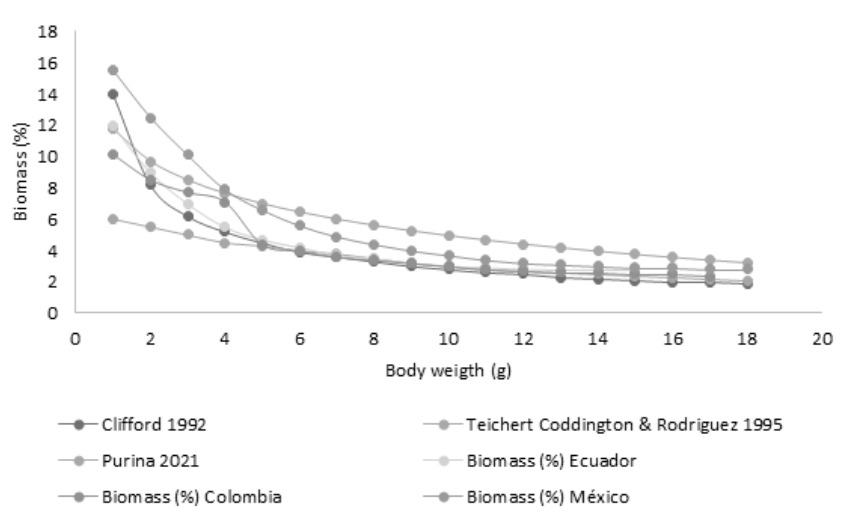

Figure 1. Feeding rates as \% Biomass related to shrimp L. vannamei body weight (g) for different cases reported by Clifford (1992) and Teichert Coddington and Rodríguez (1995) for Honduras, Davis et al. (2006) para Nicovita, Quintero and Roy (2010) for Ecuador, Colombia and México, Purina $2021 \mathrm{https}: / /$ www.nutrimentospurina.com/archivos_aplicaciones/ files_fkceditor/file/Acuacultura/Guia_Alimentacion.pdf

Figura 1. Tasas de alimentación en porcentaje de biomasa en función del peso corporal (g) del camarón L. vannamei para diferentes casos analizados que incluyen datos reportados por; Clifford (1992) y Teichert Coddington and Rodríguez (1995) para Honduras, Davis et al (2006) para Nicovita, Quintero y Roy (2010) para Ecuador, Colombia y México, Purina 2021 https://www.nutrimentospurina.com/archivos_aplicaciones/files_fkceditor/ file/Acuacultura/Guia_Alimentacion.pdf

\section{DPI mathematical functions related to body weight (BW)}

The DPI mathematical function developed in this study from experimental data reported by Kureshy and Davis (2002) with similar protein efficiency levels, was DPI $=44.7$ $\mathrm{BW}^{-0.714}$ (Figure 2).

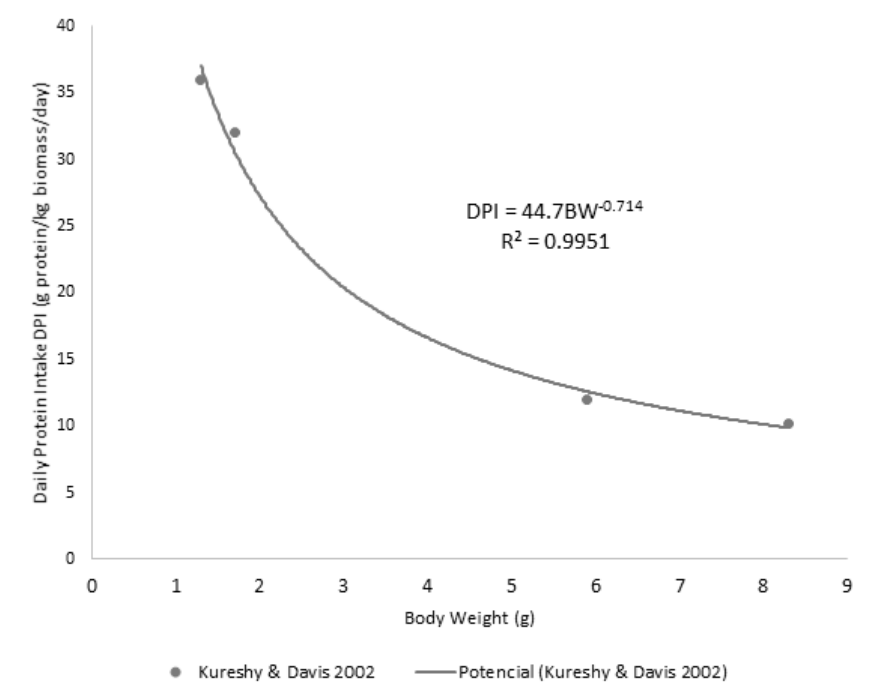

Figure 2. Daily protein intake ( $\mathrm{g}$ prot $/ \mathrm{kg}$ biomass/day) mathematical function ( $\mathrm{DPI}=44.7(\mathrm{BW})^{-0.714}$ ) related to $L$. vannamei Body weight $(\mathrm{BW})$ in grams, obtained in this study from experimental data reported by Kureshy and Davis (2002), using selected DPI data for different shrimp sizes only where protein retention (\%) was similar (37.2\% in average).

Figura 2. Función matemática de la Ingesta Diaria de Proteína (g prot/ kg biomasa /día), IDP=44.7PC-0.714, en función del peso corporal (PC) en gramos, obtenida en este estudio a partir de datos experimentales reportados por Kureshy and Davis (2002), utilizando datos de IDP seleccionados para diferentes pesos corporales donde la retención de proteína (\%) fue similar ( $37.2 \%$ en promedio).
Figure 3 show the DPI mathematical functions adjusted from transformed data obtained from the different feeding tables, compared with the DPI mathematical function reported in figure 2 .

DPI mathematical functions: $\mathrm{DPI}=65.58 \mathrm{BW}^{-0.714}$, DPI $=53.64 \mathrm{BW}^{-0.714}, \mathrm{DPI}=44.7 \mathrm{BW}^{-0.714}$ and $\mathrm{DPI}=37.76 \mathrm{BW}^{-0.714}$, corresponding to $80,100,120$ and $140 \%$ DPI respectively, were $\mathrm{DPI}=44.7 \mathrm{BW}^{-0.714}$ for $L$. vannamei is considered $100 \%$, are presented in figure 4 and compared to the transformed DPI data obtained from feeding tables reviewed in this study.

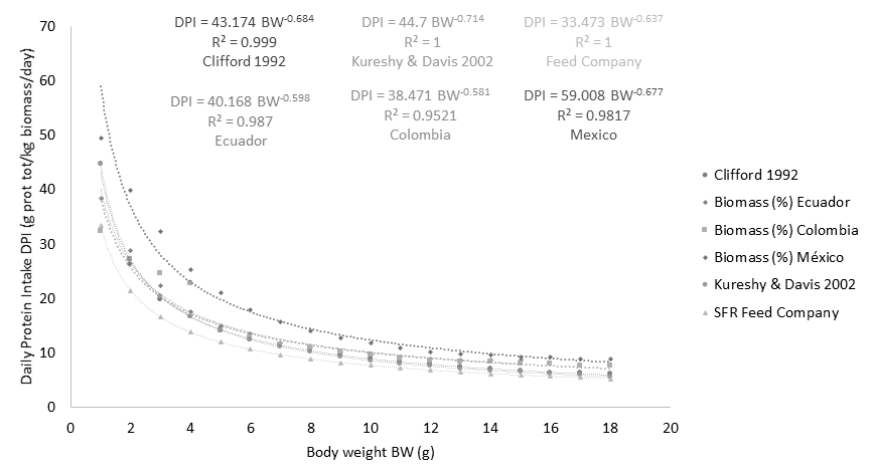

Figure 3. Daily protein intake (g prot/kg biomass/day) mathematical functions related to $L$. vannamei Body weight ( $\mathrm{g}$ ) adjusted from transformed data contained in different feeding tables based on \%Biomass related to Body Weight (Clifford 1992, Davis et al., 2006 and Quintero and Roy 2010, for Ecuador, Colombia and México), compared with DPI=44.7(BW) ${ }^{-0.74}$.

Figure 3. Funciones matemáticas de la ingesta diaria de proteína (g prot/ $\mathrm{kg}$ biomasa/día) en función del peso corporal ( $\mathrm{g}$ ) de L. vannamei ajustadas a partir de datos transformados provenientes de diferentes tablas de alimentación de \%Biomasa en relación con el Peso Corporal (Clifford 1992, Davis et al 2006 y Quintero and Roy 2010 para Ecuador, Colombia y México) comparadas con DPI $=44.7 \mathrm{BW}^{-0.74}$.

\section{First trial: Daily protein intake (DPI)}

Significant differences were found in weight gain with different DPI functions (Table 3), with organisms fed 80 and $100 \%$ DPI showing significantly less growth than those fed 120 and $140 \%$. At the end of the experiment, no significant differences were found between 120 and $140 \%$. We found significant differences in specific growth rate, average weekly growth, feed conversion rate, protein efficiency and nitrogen retention (Table 4). The organisms fed with 80 and $140 \%$ DPI rates showed the lowest and highest values respectively in all cases. Three homogeneous groups were found in the

Table 3. L. vannamei Weight gain (g) under laboratory conditions fed with $80,100,120$ and $140 \%$ (crude protein) Daily Protein Intake (DPI).

Tabla 3. Ganancia en peso (g) de $L$. vannamei bajo condiciones de laboratorio alimentados con $80,100,120$ y $140 \%$ (proteína cruda) de ingesta diaria de proteína (IDP).

\begin{tabular}{ccccc}
\hline Time & \multicolumn{4}{c}{ Daily Protein Intake (\%) } \\
\hline (Week) & $\mathbf{8 0}$ & $\mathbf{1 0 0}$ & $\mathbf{1 2 0}$ & $\mathbf{1 4 0}$ \\
\hline 1 & $0.62 \pm 0.11 \mathrm{a}$ & $0.62 \pm 0.01 \mathrm{a}$ & $0.71 \pm 0.04 \mathrm{a}$ & $0.79 \pm 0.17 \mathrm{a}$ \\
2 & $1.24 \pm 0.07 \mathrm{a}$ & $1.31 \pm 0.06 \mathrm{ab}$ & $1.53 \pm 0.07 \mathrm{~b}$ & $1.73 \pm 0.18 \mathrm{c}$ \\
3 & $3.03 \pm 0.10 \mathrm{a}$ & $3.08 \pm 0.06 \mathrm{ab}$ & $3.39 \pm 0.15 \mathrm{~b}$ & $3.79 \pm 0.21 \mathrm{c}$ \\
\hline 4 & $3.77 \pm 0.19 \mathrm{a}$ & $4.02 \pm 0.08 \mathrm{a}$ & $4.58 \pm 0.21 \mathrm{~b}$ & $5.00 \pm 0.30 \mathrm{~b}$ \\
\hline 5 & $3.84 \pm 0.16 \mathrm{a}$ & $4.3 \pm 0.18 \mathrm{a}$ & $5.01 \pm 0.28 \mathrm{~b}$ & $5.60 \pm 0.37 \mathrm{~b}$ \\
\hline
\end{tabular}


Table 4. Performance of $L$. vannamei under laboratory conditions fed with $80,100,120$ and $140 \%$ (crude protein) Daily Protein Intake (DPI).

Tabla 4. Desempeño de $L$. vannamei en condiciones de laboratorio alimentados con 80, 100, 120 y $140 \%$ (proteína cruda) de Ingesta Diaria de Proteína (IDP).

\begin{tabular}{ccccc}
\hline & \multicolumn{4}{c}{ Daily Protein Intake (\%DPI) } \\
\cline { 2 - 5 } & $\mathbf{8 0}$ & $\mathbf{1 0 0}$ & $\mathbf{1 2 0}$ & $\mathbf{1 4 0}$ \\
\hline WG (\%) & $481.14 \pm 13.98 \mathrm{a}$ & $526.34 \pm 6.87 \mathrm{ab}$ & $602.55 \pm 34.10 \mathrm{bc}$ & $636.81 \pm 61 \mathrm{c}$ \\
SGR (\%) & $3.14 \pm 0.06 \mathrm{ab}$ & $3.32 \pm 0.03 \mathrm{ab}$ & $3.59 \pm 0.11 \mathrm{bc}$ & $3.7 \pm 0.20 \mathrm{c}$ \\
AWG (g) & $0.76 \pm 0.03 \mathrm{a}$ & $0.85 \pm 0.36 \mathrm{a}$ & $1.00 \pm 0.5 \mathrm{~b}$ & $1.12 \pm 0.07 \mathrm{~b}$ \\
S (\%) & $95.83 \pm 4.81 \mathrm{a}$ & $88.8 \pm 4.81 \mathrm{a}$ & $97.2 \pm 4.81 \mathrm{a}$ & $94.4 \pm 4.81 \mathrm{a}$ \\
FCR & $1.12 \pm 0.02 \mathrm{a}$ & $1.26 \pm 0.03 \mathrm{ab}$ & $1.32 \pm 0.07 \mathrm{~b}$ & $1.41 \pm 0.09 \mathrm{~b}$ \\
PER & $2.37 \pm 0.12 \mathrm{a}$ & $2.09 \pm 0.1 \mathrm{~b}$ & $2.01 \pm 0.05 \mathrm{~b}$ & $1.89 \pm 0.05 \mathrm{~b}$ \\
NR & $40.45 \pm 0.90 \mathrm{a}$ & $35.76 \pm 0.03 \mathrm{~b}$ & $34.38 \pm 1.92 \mathrm{~b}$ & $32.26 \pm 2.09 \mathrm{~b}$ \\
\hline
\end{tabular}

WG=Weight gain, $S G R=$ Specific growth rate, $A W G=$ Average weekly growth, $\mathrm{S}=$ Survival rate, $\mathrm{FCR}=$ Feeding conversion ratio, $\mathrm{PER}=$ Protein efficiency ratio. C:N ratio of diet $=7.98$

specific growth rate, showing significantly differences at 140 $\%$. A higher feed conversion rate was found in treatments with 120 and $140 \%$. The protein efficiency ratio and nitrogen retention showed two homogeneous groups, where $(120$ \%) $\mathrm{DPI}=53.64 \mathrm{BW}^{-0.714}$ was better in growth, PER and NR. No differences were found in survival rate due to DPI at any level.

\section{Second trial: Bioassay with five $\mathrm{CBH}: \mathrm{CP}$ ratios using same DPI level and Lip:CP ratio}

We found a significant effect by $\mathrm{CBH}: \mathrm{CP}$ ratio on weight gain, specific growth rate, feed conversion rate, protein efficiency ratio and nitrogen retention (Table 5). No significant differences were found in the survival rate. Significant differences were observed between treatments with 2.1 and 1.5 compared to the rest $\mathrm{CBH}: \mathrm{CP}$ ratios. The specific growth rate also presented significant differences between treatments, with higher values in 2.1 and $1.5 \mathrm{CBH}: \mathrm{CP}$. The feed conversion rate and protein efficiency ratio showed the highest values at the highest levels of CBH:CP (2.1 and 1.5). The weekly average growth showed an effect by Carbohydrate:Crude protein rate, with higher values in 2.1, 1.5 and 1.1 CBH:CP. Nitrogen retention was statistically higher in 2.1 and lower in $0.6 \mathrm{CBH}: \mathrm{CP}$ respectively. Survival rate was not affected by $\mathrm{CBH}: \mathrm{CP}$ ratios.

\section{DISCUSSION}

The review of the feeding tables shows great variability in \%Biomass for Shrimp BW lower than 5 grams (Figure 1), mainly due to the variability in the protein content (level or percentage) in feeds recommended for small shrimps. In this sense, feeding tables not necessarily represent the real amount of protein provided to the aquaculture system, since they are not related with the protein content in feeds. When different protein levels in feeds are tested (25-45\% CP), the use of feeding tables as a protocol to feed the shrimps, with same feeding ratio based on \% Biomass and BW, implicitly provide different amounts of protein according to the feed protein level (\%), generating differences not necessarily due to the protein level, but the real amount of protein provided for shrimps. Kureshy and Davis (2002), using the same approach, tested different amounts of protein (g protein/ $\mathrm{kg}$ shrimp biomass/day) as DPI for different shrimp BW and found a growth rate increase related to DPI increase, but also found an increase in Protein Efficiency (PE) from lower to medium DPI, but a decrease in PE at greater amount of DPI. Therefore, the maximum growth at high DPI have consequences in lowering PE and Nitrogen retention (NR), with side effects on nitrogen residuals in the aquaculture environment.

For this reason, in this study, we select the DPI data provided by Kureshy and Davis (2002), for different BWs with the better Protein retention ( $37.2 \%$ in average) to adjust the mathematical model DPI $=44.7(\mathrm{BW})^{-0.714}$ (Figure 2 ). Using this mathematical model, we adjust the transformed data provided by the feeding tables from different sources and found not only high correlation $(>0.9501)$, but surprisingly a similar trend between the adjusted DPI model obtained in this study from data reported by Kureshy and Davis (2002), compared to the DPI adjusted from Clifford (1992) data, recommended by relevant shrimp feed companies like Nicovita and Purina (Figure 3). The four different variants in DPI mathematical functions $\left(\mathrm{DPI}=37.76(\mathrm{BW})^{-0.714}, \mathrm{DPI}=44.7(\mathrm{BW})^{-0.714}\right.$, $\mathrm{DPI}=53.64(\mathrm{BW})^{-0.714}$, and $\left.\mathrm{DPI}=65.58(\mathrm{BW})^{-0.714}\right)$, respectively corresponding to $80,100,120$ and $140 \% \mathrm{DPI}=44.7(\mathrm{BW})^{-0.714}$

Table 5. Performance of $L$. vannamei cultured in laboratory with five experimental diets with different $C B H: C P$ ratios and same Lip:CP ratio (crude protein).

Tabla 5. Desempeño de $L$. vannamei cultivado en laboratorio con cinco dietas experimentales con cinco proporciones diferentes $\mathrm{CHO}: \mathrm{CP}$ y una proporción Lip:CP (proteína cruda)

\begin{tabular}{lccccccccc}
\hline CBH:P & Lip/P & C:N & WG & SGR & AWG & S & FCR & PER & NR \\
\hline $\mathbf{( g / g )}$ & $(\mathbf{g} / \mathbf{g})$ & & $(\%)$ & $\left(\%\right.$. day $\left.^{-1}\right)$ & $(\mathbf{g})$ & $(\%)$ & & & \\
\hline 2.1 & 0.2 & 12.15 & $323.3 \pm 15.7 \mathrm{a}$ & $2.3 \pm 0.10 \mathrm{a}$ & $1.27 \pm 0.12 \mathrm{a}$ & $86.5 \pm 5.8 \mathrm{a}$ & $2.25 \pm 0.08 \mathrm{a}$ & $1.84 \pm 0.07 \mathrm{a}$ & $30.65 \pm 1.93 \mathrm{a}$ \\
1.5 & 0.2 & 9.87 & $297.4 \pm 7.6 \mathrm{ab}$ & $2.2 \pm 0.10 \mathrm{ab}$ & $1.14 \pm 0.06 \mathrm{ab}$ & $94.4 \pm 2.8 \mathrm{a}$ & $2.16 \pm 0.04 \mathrm{ab}$ & $1.60 \pm 0.03 \mathrm{~b}$ & $25.87 \pm 0.78 \mathrm{~b}$ \\
\hline 1.1 & 0.2 & 8.51 & $267.0 \pm 1.5 \mathrm{~b}$ & $2.0 \pm 0.10 \mathrm{~b}$ & $1.14 \pm 0.19 \mathrm{~b}$ & $89.5 \pm 6.7 \mathrm{a}$ & $2.07 \pm 0.01 \mathrm{ab}$ & $1.40 \pm 0.001 \mathrm{bc}$ & $23.33 \pm 0.13 \mathrm{bc}$ \\
0.8 & 0.2 & 7.64 & $269.0 \pm 9.7 \mathrm{~b}$ & $2.0 \pm 0.10 \mathrm{~b}$ & $1.22 \pm 0.12 \mathrm{ab}$ & $92.3 \pm 7.7 \mathrm{a}$ & $1.95 \pm 0.08 \mathrm{~b}$ & $1.37 \pm 0.06 \mathrm{c}$ & $22.28 \pm 1.67 \mathrm{c}$ \\
0.6 & 0.2 & 7.00 & $285.3 \pm 5.2 \mathrm{ab}$ & $2.1 \pm 0.03 \mathrm{ab}$ & $1.04 \pm 0.05 \mathrm{~b}$ & $89.3 \pm 2.3 \mathrm{a}$ & $1.66 \pm 0.02 \mathrm{c}$ & $1.45 \pm 0.02 \mathrm{bc}$ & $23.91 \pm 0.58 \mathrm{bc}$ \\
\hline
\end{tabular}

WG=Weight gain, $\mathrm{SGR}=$ Specific growth rate, $\mathrm{AWG}=$ Average weekly growth, $\mathrm{S}=$ Survival rate, $\mathrm{FCR}=$ Feeding conversion ratio, $\mathrm{PER}=$ Protein efficiency ratio. C:N ratio of diet $=7.98$ 
for L. vannamei, cover and represent the different DPI data calculated from the feeding tables reviewed in this study (Clifford, 1992; Kureshy and Davis, 2002; Davis et al., 2006; Quintero and Roy, 2010). For this reason were used to select the DPI mathematical model to evaluate the different Carbohydrate:Crude Protein ratios with same DPI and shrimp BW (Figure 4).

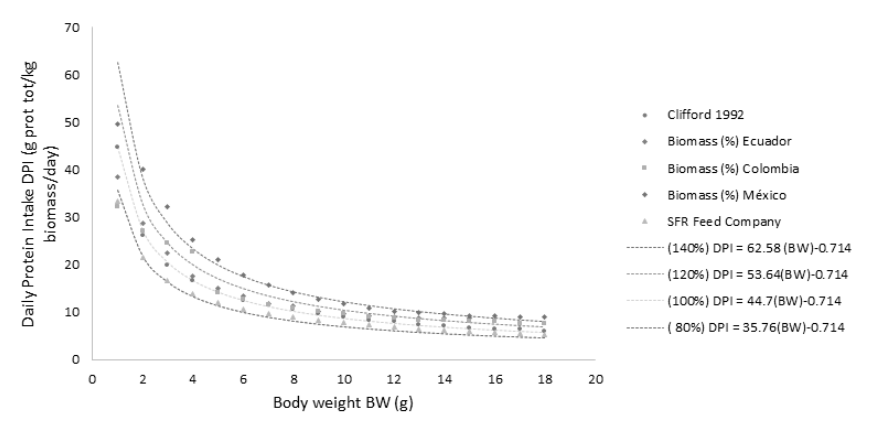

Figure 4. Daily Protein Intake (g prot/kg biomass/day) mathematical functions: $\mathrm{DPI}=37.76(\mathrm{BW})-0.714, \mathrm{DPI}=44.7(\mathrm{BW})-0.714, \mathrm{DPI}=53.64(\mathrm{BW})-0.714$ and $\mathrm{DPI}=65.58$ (BW)-0.714, respectively corresponding to $80,100,120$ and $140 \% \mathrm{DPI}=44.7(\mathrm{BW})-0.714$ for L. vannamei, where BW is Body weight $(\mathrm{g})$, compared with DPI data calculated from different feeding tables (\%Biomass related to Body Weight).

Figura 4. Funciones matemáticas de Ingesta Diaria de Proteína (g prot/kg biomasa/día): IDP=37.76(PC)-0.714, IDP=44.7(PC)-0.714, $I D P=53.64(P C)-0.714$ e IDP=65.58(PC)-0.714, corresponden respectivamente a $80,100,120$ y $140 \%$ IDP=44.7(PC)-0.714 para L. vannamei Donde PC es el peso corporal (g), comparadas con datos de IDP calculados a partir de datos provenientes de diferentes tablas de alimentación (\%Biomasa con relación al Peso Corporal).

We observed that variations in DPI levels using the same protein and $\mathrm{CBH}: \mathrm{CP}$ ratios have a direct effect on growth, PER and NR, showing a linear increase in all growth parameters with DPI. In survival, this trend was not observed. A variation of the optimal protein requirements of $L$. vannamei from 20 to $45 \%$ has been reported (Kureshy and Davis, 2002, Hu et al., 2008; Yaemssoksawat et al., 2008; Sui et al., 2015, Lee and Lee, 2018), where these variations are influenced by the stocking density and aquaculture system (Brito et al., 2001). Xia et al. (2010) reported that adequate protein values in diet under high-density conditions, in the absence of natural productivity, must be at least $43 \%$, results in a linear growth as protein increases with a slight decrease at higher percentages. Similarly, Jang et al. (2014) found a greater weight gain and specific growth rate feeding with 40 and $45 \%$ protein, not having significant differences between them, and suggesting that values higher than $40 \%$ are not necessary.

In the experiments with variants of the DPI mathematical model, we find an increase in growth parameters and feed conversion rates, but a decrease in protein efficiency and nitrogen retention with the increase in DPI level. Although no significant differences were found between the highest DPI ( $120 \%$ and $140 \%)$, in terms of growth parameters and nitrogen retention, these results suggest that the change in the feed protein levels must be adjusted by DPI mathematical functions to compare feeds with different formulas or
$\mathrm{CBH}: \mathrm{CP}$ ratios. In this study, a decrease in protein efficiency and nitrogen retention was found with the increase in DPI at similar levels of protein content and $\mathrm{CBH}: \mathrm{CP}$ ratio, suggesting that the rest of the energy substrates in the diet provided favor the adequate use of this.

Regarding DPI, the levels used agree with the daily protein level required by L. vannamei determined by Kureshy and Davies (2002), Clifford (1992) and Tacon (2002), as well as the recommendations by relevant shrimp feed companies such as Nicovita (Clifford, 1992) and Purina (2021). In addition, the flexibility in the mathematical model may favor their adjustment to obtain better performance of the different aquaculture systems in economic and environmental terms, also testing different genetic linages and proportionality between different ingredients and protein.

Modern aquaculture requires maximum growth with a reduction in protein intake and nitrogen residuals. The protein in the diet can be reduced if the energy required comes from another source such as carbohydrates, which can reduce the emission of residual nutrients and feed costs (Zainuddin et al., 2014). The results obtained in this study shows that increasing the proportion of carbohydrates/ protein in feeds, with the same DPI mathematical model that meets the requirements of the organisms, will significantly favor the performance of the system without cost in survival. Carbohydrates can provide important energy content and can be used by shrimp for the synthesis of chitin, however, their ability to use them is limited, due to their low capacity to digest and regulate plasma glucose concentrations (Guo et al., 2006).

It has been observed that the best performance is at levels around $40 \%$. Zainuddin et al. (2014) determined the best growth for $L$. vannamei with $38 \%$ carbohydrates compared to lower levels, suggesting that high carbohydrates levels can be used if it is fed with a high frequency in small amounts, which favors the use of carbohydrates and increases fat reserves with a more efficient lipogenesis process. Pascual et al. (2004) found better immunological performance with high carbohydrates levels, determining that these can favor the functioning of the organisms feeding appropriately. In this sense, we observed that by supplying the same DPI and Lip:CP ratio, the differential contribution of carbohydrates increasing $\mathrm{CBH}: \mathrm{CP}$ ratio to 2:1 has a significant effect on growth, protein efficiency and nitrogen retention without cost in survival.

\section{CONCLUSION}

Feeding based on DPI $=53.64(\mathrm{BW})^{-0.714}$ corresponding to $120 \% \mathrm{DPI}=44.7(\mathrm{BW})^{-0.714}$, is sufficient to achieve optimal growth of $L$. vannamei juveniles, at least within a range of 2 to $8 \mathrm{~g}$ in clear water systems without natural productivity. DPI mathematical model show elasticity to adapt to different shrimp feed management scenarios and can be used to evaluate feed formulations in the context of genetic linages. A significant effect on weight gain, specific growth rate, feed conversion rate, protein efficiency and nitrogen retention 
were found due to $\mathrm{DPI}$ levels and $\mathrm{CBH}: \mathrm{CP}$ ratios. Growth parameters and feed conversion rates increase in both cases, but protein efficiency and nitrogen retention diminish with DPI levels using feeds with similar protein level and $\mathrm{CBH}: \mathrm{CP}$ ratio and increases with $C B H: C P$ ratios at same DPI level using feeds with low fishmeal content, with potential benefits to decrease risks of contamination and eutrophication. Satisfying the protein needs of the organisms, it allows the use of $\mathrm{CBH}: \mathrm{CP}$ ratios to maximize the use of protein in feeds and performance of the aquaculture system without complications, such as decreases growth and mortality or environmental impacts like pond or ecosystem eutrophication.

\section{ETHICS STATEMENT}

Mexican law excludes fish and crustacean taxa with regard to (a) humane care during the transport of animals (NOM-051-ZOO-1995), (b) the technical specifications for the production, care and use of animals in laboratory conditions (NOM-062-ZOO-1999) and (c) the humane sacrifice of domestic and wild animals (NOM-033-ZOO-1995). Nonetheless, we voluntarily followed special procedures for shrimp care, at the end of the experiments were sacrificed in ice water.

\section{ACKNOWLEDGES}

The authors want to thank Marcos Cadena, Sonia Rocha, Sandra de la Paz for their valuable technical assistance during the experimental feed formulation, laboratory analysis and aquaculture experiments.

\section{REFERENCES}

Akiyama, H., Nakamura, N., Nagasaka, S., Sakamaki, S. and Onozawa, Y. 1992. Hypercalcaemia due to all-trans retinoic acid. Lancet. 339, 308-309. https://doi.org/10.1016/01406736(92)91382-i

Brito, R., Rosas, C., Chimal, M.E. and Gaxiola, G. 2001. Effect of different diets on growth and digestive enzyme activity in Litopenaeus vannamei (Bone, 1931) early post-larvae. Aquaculture Research. 32: 257-266. https://doi.org/10.1046/ j.1365-2109.2001.00548.x

Clifford, H.C. 1992. Marine shrimp pond management: Review. Pages 110-137 in J. Wyban, editors. Proceeding of the special session on shrimp farming. The World Aquaculture Society. Baton Rouge, LA, USA.

FAO. 2020. The state of world fisheries and aquaculture: Sustainability in action. FAO, Rome. https://doi.org/10.4060/ ca9229en.

Gil-Núñez, J. C., Martínez-Córdova, L.R., Servín-Villegas, R., Magallon-Barajas, F.J., Bórquez-López, R.A., GonzálezGalaviz, J.R., and Casillas-Hernández, R. 2020. Production of Penaeus vannamei in low salinity using diets formulated with different protein sources and percentages. Latin American Journal of Aquatic Research, 48, 396-405. https:// doi.org/10.3856/vol48-issue3-fulltext-2361.

González-Félix, M.L., Lawrence, A.L., Gatlin, D.M. and PérezVelázquez, M. 2002. Growth, survival, and fatty acid composition of juvenile Litopenaeus vannamei fed different oils in the presence and absence of phospholipids. Aquaculture, 205, 325-343. https://doi.org/10.1016/S00448486(01)00684-6.
Guo, R., Liu, Y.J., Tian, L.X. and Huag, J.W. 2006. Effect of dietary cornstarch levels on growth performance, digestibility, and microscopic structure of white shrimp Litopenaeus vannamei reared in brackish water. Aquaculture Nutrition 12, 83-88. https://doi.org/10.1111/j.1365-2095.2006.00384.x

Güroy, D., Sahin, I., Güroy, B., Altin, A. and Merrifield, D.L. 2012. Effect of dietary protein level on growth performance and nitrogen excretion of the yellow tail cichlid, Pseudotropheus acei. Israeli Journal of Aquaculture, 64:1. DOI:10.46989/001c.20656

Hu, Y., B. Tan, K. Mai, Q. Ai, S. Zheng, and K. Cheng. 2008. Growth and body composition of juvenile whiteleg shrimp, Litopenaeus vannamei, fed different ratios of dietary protein to energy. Aquaculture Nutrition. 14: 499-506. https://doi. org/10.1111/j.1365-2095.2007.00555.x

Jannalhulla, R., Chitra, V., Vasanthakumar, D., Nagavel, A., Ambasankar, K., Muralidhar, M. and Syama-Dayal, J. 2019. Effect of dietary lipid/essential fatty acid level on Pacific whiteleg shrimp, Litopenaeus vannamei (Boone, 1931) reared at three different water salinities-Emphasis on growth, hemolymph indices and body composition. Aquaculture. 734405. https://doi.org/10.1016/j.aquaculture.2019.734405.

Jang, I.K., Shahkar, E., Kim, S.K., Yun, H., 2014. Evaluation of optimum dietary protein levels for juvenile white shrimp (Litopenaeus vannamei). Journal of Crustacean Biology, 34, 552-558. https://doi.org/10.1163/1937240X-00002267

Kureshy, N. and Davis, D. A. 2002. Protein requirements for maintenance and maximum weight gain for the Pacific white shrimp, Litopenaeus vannamei. Aquaculture, 204, 125143. https://doi.org/10.1016/S0044-8486(01)00649-4.

Lee, C., and J. K. Lee. 2018. Dietary protein requirement of Pacific white shrimp Litopenaeus vannamei in three different growth stages. Fisheries and Aquatic Sciences, 21, 30. https:// doi.org/10.1186/s41240-018-0105-0.

Limsuwan, C. and Junratchakoo, P. 2004. Shrimp Culture Industry of Thailand. Magic Publishing, Bangkok.

Liu, D. H., He, J.G., Liu, Y.J., Zheng, S.X. and Tian, L.X. 2005. Effects of dietary protein levels on growth performance and immune condition of Pacific white shrimp, Litopenaeus vannamei juveniles at very low salinity. Acta Scientiarum Naturalium Universitatis Sunyatseni. 44: 217-223.

Pascual, C., Zenteno, E., Guzon, G., Sanchez, A., Gaxiola, A., Tabeada, G., Suarez, J., Rosas, T., 2004. Litopenaus vannamei juveniles have an energetic balance and immunological response to dietary protein. Aquaculture, 236, 431-450. https://doi.org/10.1016/j.aquaculture.2004.01.015.

Quintero, H. E., Roy, L. A. 2010. Practical feed management in semi-intensive systems for shrimp culture: The shrimp book 2010 pp.443-453 ref.15. Alday-Sanz, V. (Editores), ISBN: 9781904761594, Record Number: 20113353954, Nottingham University Press, Nottingham, UK.

Shiau, S.Y. 1997. Utilization of carbohydrates in warm water fish with reference to tilapia, Oreochromis niloticus. Aquaculture, 151, 79-96. https://doi.org/10.1016/S0044-8486(96)014913.

Smith, L.L., Lee, P.G., Lawrence, A.L. and Strawn, K. 1985. Growth and digestibility by three sizes of Penaeus vannamei Boone: effects of dietary protein level and protein source. Aquaculture 46, 85-96. https://doi.org/10.1016/00448486(85)90193-0. 
Sui, L., Ma, G. and Deng, Y. 2015. Effect of dietary protein level and salinity on growth, survival, enzymatic activities and amino-acid composition of the white shrimp Litopenaeus vannamei (Boone, 1931) juveniles. Crustaceana. 88: 82-95. https://doi.org/10.1163/15685403-00003390

Tacon, A.G.J. and Akiyama, D. 1997. Feed Ingredients. In: Crustacean Nutrition, Advances in World Aquaculture, Volume 6. World Aquaculture Society, Baton Rouge, US.

Wang, X.D., E.C. Li, S.F. Wang, J.G. Qin, X.F. Chen, Q.M. Lai, K. Chen, C. Xu, L. Gan, N. Yu, Z.Y. Du and L.Q. Chen. 2015. Proteinsparing effect of carbohydrate in the diet of white shrimp Litopenaeus vannamei at low salinity. Aquaulture Nutrition. 21: 904-912.

Wasielesky, W., Atwood, H., Browdy, C. 2006. Effect of natural production in a zero-exchange suspended microbial flocbased super-intensive culture system for white shrimp Litopenaeus vannamei. Aquaculture, 258, 396-403. https:// doi.org/10.1016/j.aquaculture.2006.04.030.

Xia, S., Li, Y., Wang, W., Rajkumar, M., Paramasivam, K., Vasagam, K. and Wang, H. 2010. Influence of dietary protein levels on growth, digestibility, digestive enzyme activity, and stress tolerance in white-leg shrimp, Litopenaeus vannamei (Boone, 1931), reared in high-density tank trials. Aquaculture
Research, 41, 1845-1854. https://doi.org/10.1111/j.13652109.2010.02585.x.

Xu, C., Li, E,C,m Liu, Y. and Shifeng, W. 2017. Effect of dietary lipid level on growth, lipid metabolism and health status of the Pacific white shrimp Litopenaeus vannamei at two salinities. Aquaculture Nutrition. 24 (1). DOI:10.1111/anu.12548

Yaemsooksawat N., O. Jintasataporn, N. Areechon, S. Puntuma and Ch. Thongtuak. 2009. Effect of dietary protein level on growth and immunity of Litopenaeus vannamei, Boone 1931. Songklanakarin Journal of Science and Technology. 31(1): 15-20.

Zainuddin, H., Haryati H. and Aslamyah, S. 2014. Effect of dietary carbohydrate levels and feeding frequencies on growth and carbohydrate digestibility of white shrimp Litopenaeus vannamei under laboratory conditions. Journal of Aquaculture Research Development. 5, 274. https://doi. org/10.4172/2155-9546.1000274

Zhang, S., Li, J., Wu, X., Zhong, W., Xian, J., Liao, S. and Wang, A. 2013. Effects of different dietary lipid levels on the growth, survival, and immune-related gene expression in Pacific white shrimp, Litopenaeus vannamei. Fish and Shellfish Immunology. 34, 1131-1138. https://doi.org/10.1016/j. fsi.2013.01.016 